\title{
Interference of Urochloa plantaginea on Morphophysiology and Yield Components of Black Beans
}

\author{
Milena Barretta Franceschetti ${ }^{1}$, Leandro Galon ${ }^{1}$, Maico André Michelon Bagnara ${ }^{1}$, Renan Pawelkiewicz ${ }^{1}$, \\ Leonardo Brunetto ${ }^{1}$, Adilson Lemos Rezende ${ }^{1}$, Juliane Cervi Portes ${ }^{1}$, Vinicius Soligo ${ }^{1}$, \\ Gismael Francisco Perin ${ }^{1}$, Janaíne Oliveira Toso ${ }^{1}$, Francisco Wilson Reichert Júnior ${ }^{2} \&$ César Tiago Forte $^{3}$ \\ ${ }^{1}$ Dpartmet of Agronomy, Federal University of Fronteira Sul, Erechim, Brazil \\ ${ }^{2}$ Department of Genetic Resources, Federal University of Santa Catarina, Florianópolis, Brazil \\ ${ }^{3}$ Department of Agronomy, Federal University of Santa Maria, Santa Maria, Brazil \\ Correspondence: Milena Barretta Franceschetti, Department of Agronomy, Federal University of Fronteira Sul, \\ Erechim, Brazil. Tel: 55-549-9987-1396. E-mail: milena.barretta@hotmail.com
}

Received: March 20, 2019

doi:10.5539/jas.v11n9p272

\author{
Accepted: April 26, $2019 \quad$ Online Published: June 30, 2019 \\ URL: https://doi.org/10.5539/jas.v11n9p272
}

\begin{abstract}
Among the factors which affect crop productivity, there are weeds which compete for environment resources. The objective of this work was to determine the periods of interference of alexandergrass on the morphophysiology and productivity components of black beans. The experiment was conducted in a complete randomized block design with four replications. The bean cultivar of the black type used was IPR Uirapuru, being the treatments separated in two models of interference: in the coexistence group, the crop of the bean lived with the alexandergrass by growing periods of $0,7,14,21,28,35,42$ and throughout the cycledays after emergence and throughout the cycle; in the control group the crop was kept free of the infestation for the same periods described previously. At $42 \mathrm{DAE}$ were evaluated the variables related to plant morphology and physiology (height of bean plants, number of trifoliate leaves, dry mass plant, number of grains pods, number od pods plants, stomatal conductance, internal $\mathrm{CO}_{2}$ concentration, photosynthetic activity, efficiency of carboxylation, efficient use of water, transpiration rate). Considering the results, it is possible to conclude that the critical period of interference prevention (CPIP) comprises 24 to 50 DAE, the period before the interference (PBI) was $24 \mathrm{DAE}$ and the total period of interference prevention (TPIP) was 50 days and that the morphological and physiological variables of the plants were negatively affected in the coexistence with the alexandergrass when compared to the treatments kept free of weeds throughout the crop cycle.
\end{abstract}

Keywords: Phaseolus vulgaris, weed, competitive ability

\section{Introduction}

Beans (Phaseolus vulgaris L.) are considered one of the main foods present in the table of the Brazilian population, presenting great cultural importance and source of nutrients such as iron, proteins and carbohydrates (CONAB, 2018). Brazil is the 3rd largest producer of beans in the world, behind Myanmar and India. In the $16 / 17$ crop the bean crop occupied about 3.2 million hectares, reaching average productivity of $1,069 \mathrm{~kg} / \mathrm{ha}$ (CONAB, 2018).

Among the factors responsible for the low yields of bean grains in Brazil, the interference caused by weeds stands out. Weeds compete with the crop by environment resources like; water, nutrients and light, release allelopathic substances and still serve as hosts of many insects and diseases that can affect the yield also the quality of harvested grains (Barroso et al., 2010; Balbinot et al., 2016).

Competition is the most important factor in terms of interference, it varies according to the botanical composition of the environment and occurs in both natural communities and agroecosystems, and can be influenced by spacing, edaphoclimatic conditions, type of management adopted, abundance and distribution of weeds, among others (Xiao-Yan et al., 2015).

It is noteworthy that plants with C4 metabolism are more competitive than C3 plants (Taiz et al., 2017). This occurs because $\mathrm{C} 4$ plants exhibit higher activity at higher temperatures and saturation does not occur due to excess light, whereas C3 plants saturate to a lower level of luminosity and when at high temperatures they stop 
the photosynthetic activity and start the photorespiration. Another characteristic that confers the $\mathrm{C} 4$ plants present greater competitiveness is related to these have better efficiency in the use of water, with this the plant transpires less, allowing greater accumulation of biomass per mole of absorbed water (Ferreira et al., 2011).

The alexandergrass (Urochloa plantaginea) is commonly found in the southern, southeastern and midwestern regions of Brazil (Vidal et al., 2010), being an annual grass belonging to the family Poaceae, with metabolism $\mathrm{C} 4$, characterized by the aggressiveness when it competes with crops (Gallo et al., 2008). Showing a high efficiency in the exploitation of the resources of the environment (Galon et al., 2008). In high populations, alexandergrass competition may decrease soybean yield by up to $50 \%$ (Fleck et al., 2002; Silva et al., 2009b) and up to $100 \%$ maize (Galon et al., 2008).

Due to its high tillering capacity, alexandergrass predominates over the crop, forming a vigorous canopy, making it difficult to pass light to the leaves of the middle and lower third of the crop (Fleck et al., 2002). With this, the plants tend to steer towards the light (Taiz et al., 2017), influencing the height of the plants (Lacerda et al., 2010).

The stress caused by weeds on the crops can generate irreversible damages, compromising the development of the reproductive structures and consequently affect the components of grain yield (Silva et al., 2008). Lamego et al. (2004) observed a decrease in the number of pods when the soybean crop was submitted to competition.

The alexandergrass adversely affected the stature of maize plants, the height of insertion of the first ear, length of ears, number of rows per ear, number of grains per row, total grain per ear and grain yield of corn, when culture was infested by weed (Galon et al., 2008). In the cowpea crop, in competition with different weed species, Freitas et al. (2009) observed a productive reduction of $90 \%$, besides the reduction in the final stand of the crop and reduction in the number of pods per plant.

Weed interference in crops comprises three specific periods: the period before the interference (PBI) that occurs after the emergence of the crop and cohabits with a weed population with no loss of productivity, the total period of interference prevention (TPIP), occurs from sowing, in which the crop must be weed free, without grain growth, development and productivity being affected and the critical period of interference prevention (CPIP) that corresponds to the difference between the PBI and the TPIP that occurs when the competition is really high and it becomes necessary the management of the weeds (Galon et al., 2008; Agostinetto et al., 2008).

The objective of this work was to determine the periods of interference of alexandergrass on the morphophysiology and productivity components of black beans.

\section{Method}

The experiment was carried out in the field agricultural season of 2017/18, in the experimental area of the Federal University of Fronteira Sul (UFFS), Câmpus Erechim/RS, under no-tillage system, in soil classified as typical Red Latosol (Embrapa, 2013).

The experimental design was a complete randomized block design, with four replications. The experimental units were composed of $3 \mathrm{~m}$ wide plots $(6$ rows spaced $0.50 \mathrm{~m})$ by $5 \mathrm{~m}$ long $\left(15 \mathrm{~m}^{2}\right)$. In this experiment, the black bean cultivar IPR Uirapuru was used, using a mechanical seeder, in the average density of 24 plants $\mathrm{m}^{-2}$. Correction of soil fertility and other management and cultivation were carried out according to the technical recommendations for bean culture (Rolas, 2004). For the desiccation of the vegetation present in the experimental area, the herbicide glyphosate was used at the dose of $1.080 \mathrm{~L} \mathrm{ha}^{-1}$ of active ingredient.

Population surveys of the experimental area were carried out to determine the average populations of alexandergrass, a species that comes from the soil seed bank, obtaining an average population of $180 \mathrm{plants} / \mathrm{m}^{2}$. The other weeds that settled in the area were eliminated from the plots by weeding.

The treatments were separated into two models of interference: in the first, the bean culture lived with the alexandergrass for increasing periods of $0,7,14,21,28,35$ and 42 days after emergence (DAE) and throughout the cycle; being called the coexistence group, and in the second, the culture was kept free of the infestation for the same periods described previously, called control.

Was determined at $42 \mathrm{DAE}$ variables related to the physiology of plants, such as photosynthesis activity (A- $\mu \mathrm{mol}$ $\left.\mathrm{m}^{-2} \mathrm{~s}^{-1}\right)$, internal $\mathrm{CO}_{2}$ concentration $\left(\mathrm{Ci}-\mu \mathrm{mol} \mathrm{mol}^{-1}\right)$, transpiration rate $\left(\mathrm{E}-\mathrm{mol} \mathrm{H}_{2} \mathrm{O} \mathrm{m}^{-2} \mathrm{~s}^{-1}\right.$ ) and stomatal conductance (Gs-mol m $\mathrm{m}^{-1} \mathrm{~s}^{-1}$ ) measured in the middle third of the plants. The efficacy of the carboxylation (EC-mol CO $\mathrm{Cm}_{2}^{-2} \mathrm{~s}^{-1}$ ) and water use efficiency (UEA-mol $\mathrm{CO}_{2} \mathrm{~mol} \mathrm{H}_{2} \mathrm{O}^{-1}$ ) were calculated from the $\mathrm{A} / \mathrm{Ci}$ and $\mathrm{A} / \mathrm{E}$ ratio respectively. For the determination of the physiological variables, an infrared gas analyzer (IRGA) (ADC, model LCA PRO, Analytical Development Co. Ltd, Hoddesdon, UK) was used, each block being 
evaluated in one day, between eight and ten o'clock in the morning, so that if the environmental conditions were homogeneous during the analyzes.

The morphological variables of the black beans were evaluated at 42 DAE: height of plants, with a ruler graduated in centimeters, from the base of the plant to the apical meristem; number of trifoliate leaves per plant per counts; and dry mass per plant, and the plants were collected close to the soil and packed in paper bags, placed for drying in an oven with forced circulation of air, at a temperature of $60 \pm 5{ }^{\circ} \mathrm{C}$, until the meterial reaches a constant mass to be measured the dry mass of the aerial part.

In the pre-harvesting of the beans, the number of pods per plant was determined by counting the pods in five plants randomly collected within the experimental unit, using the same plants, were determining the number of grains per pod. In the harvesting of the crop was determined the productivity of the beans, when it reached $18 \%$ moisture was collected manually, in an area of $3 \times 1 \mathrm{~m}$. Eight samples of 100 grains were counted each for the measurement of the mass of one thousand grains $(\mathrm{g})$. The grain moisture was determined and the values were corrected to $13 \%$ for both grain yield and 1000 grain weight. After correction of moisture to $13 \%$ the weight was extrapolated to $\mathrm{kg} \mathrm{ha}^{-1}$.

The results were submitted to analysis of variance by the $\mathrm{F}$ test, and being these significant, we determined the period before the interference (PBI), critical period of interference prevention (CPIP), and the total period of interference prevention (TPIP) of the alexandergrass over the black bean culture.

For the determination of the periods of interference, the grain yield variable $\left(\mathrm{kg} \mathrm{ha}^{-1}\right)$ of the crop was used. For the other variables, the Tukey test was applied to evaluate the effects of the cohabitation and control periods of the alexandergrass on the bean and the $T$ test to compare the coexistence and the control within each evaluated period. All tests were performed at $\mathrm{p} \leq 0.05$.

Productivity data, standardized to $13 \%$ dry basis moisture and expressed in $\mathrm{kg} \mathrm{ha}^{-1}$, were submitted to regression analysis using the nonlinear regression model. This model obeys the following logistic equation:

$$
\mathrm{Y}=\frac{\mathrm{a}}{\left(1+e^{[-(-x-\mathrm{x} 0 \mathrm{0}) / b]}\right)}
$$

where, $Y=$ grain yield, $\mathrm{x}=$ number of days after emergence of the bean crop; $\mathrm{a}=$ maximum value of the curve; and $\mathrm{b}=$ slope of the curve; and $\mathrm{xo}=$ value of $\mathrm{x}$ at the midpoint of the sigmoid curve. Based on the regression equations, the periods of alexandergrass interference on the bean crop were determined, subtracting $5 \%$ of the estimated maximum productivity in the regression equations in relation to the treatment maintained in the absence of infestation, considered as the cost of adoption chemical control (Cousens, 1985).

\section{Results and Discussion}

The height of black bean plants in the coexistence period from 0 to 21 DAE did not differ statistically, the same occurred for the 28 and 42 DAE intervals (Table 1). In the control group of the alexandergrass, no differences between treatments were observed, except for 0 and 35 DAE. There was no significant difference when comparing the two coexistence and control groups among themselves in each period evaluated. The reduced height growth of the bean plants may be a consequence of the weed population increase, which increases both inter- and intra-specific competition. It is emphasized that the longer a weed species coexists with the crop, the greater the damage to the growth and development of the plants involved in the community (Galon et al., 2008; Silva et al., 2009a).

When analyzing the number of trifoliate leaves per plant of the bean, it was observed that there was negative interference of the alexandergrass with reduction of the variable, mainly when the culture coexisted at the beginning of the development or at $42 \mathrm{DAE}$ (Table 1). As for the control, the later the weeding of the area, more negative the effects on the number of trifoliate leaves. When comparing the coexistence and control periods between them, it was observed that the coexistence negatively affected the beans when the weeds were effected at $21 \mathrm{DAE}$ and for the control at $14 \mathrm{DAE}$. The weed interferes negatively in the development of the bean crop (Manabe et al., 2015), and U. plantaginea presents high competitive ability, causing considerable losses on the crops that infest (Galon et al., 2008).

The plant ${ }^{-1}$ dry mass did not present a significant difference between the treatments for the coexistence period, in the control, there was a lower accumulation of the variable at $35 \mathrm{DAE}$ when differing from periods 0,7 and 14 DAE (Table 1). At 0 and 14 DAE the coexistence of the beans with the alexandergrass negatively affected the dry mass of the crop plants, when comparing these periods with the control. These results may be related to the increase in the competitive capacity of the alexandergrass plants, because as the weed community increases in 
the accumulation of dry mass there is reduction of the dry mass of the crop, as also verified by Scholten et al., (2011).

Table 1. Effect of cohabitation or control periods of Urochloa plantaginea (alexandergrass) on height (cm), number of trifoliate leaves and dry mass of black bean plants IPR Uirapuru cultivar. UFFS, Erechim/RS, 2017/18

\begin{tabular}{|c|c|c|c|c|c|c|}
\hline \multirow{2}{*}{ Period in DAE } & \multicolumn{2}{|c|}{ Height of bean plants $(\mathrm{cm})$} & \multicolumn{2}{|c|}{ Number of trifoliate leaves } & \multicolumn{2}{|c|}{ Dry mass plant ${ }^{-1}(\mathrm{~g})$} \\
\hline & Coexistence & Control & Coexistence & Control & Coexistence & Control \\
\hline 0 & $44.65 \mathrm{abA}^{1}$ & $45.77 \mathrm{aA}$ & $11.00 \mathrm{dA}^{1}$ & $14.90 \mathrm{abA}$ & $5.18 \mathrm{aB}^{1}$ & $6.99 \mathrm{aA}$ \\
\hline 7 & $44.30 \mathrm{abA}$ & $42.75 \mathrm{abA}$ & $12.00 \mathrm{dA}$ & $12.50 \mathrm{bcA}$ & $5.93 \mathrm{aA}$ & $6.68 \mathrm{aA}$ \\
\hline 14 & $47.35 \mathrm{aA}$ & $42.10 \mathrm{abA}$ & $14.12 \mathrm{bA}$ & $12.10 \mathrm{bcB}$ & $4.16 \mathrm{aB}$ & $6.41 \mathrm{aA}$ \\
\hline 21 & $44.55 \mathrm{abA}$ & $42.15 \mathrm{abA}$ & $13.70 \mathrm{bcB}$ & $15.80 \mathrm{aA}$ & $6.54 \mathrm{aA}$ & $5.73 \mathrm{abA}$ \\
\hline 28 & $42.20 \mathrm{bcA}$ & $41.35 \mathrm{abA}$ & $16.90 \mathrm{aA}$ & $14.60 \mathrm{aA}$ & $6.30 \mathrm{aA}$ & $5.09 \mathrm{abA}$ \\
\hline 35 & $39.10 \mathrm{cA}$ & $38.65 \mathrm{bA}$ & $12.32 \mathrm{cdA}$ & $10.65 \mathrm{cA}$ & $3.10 \mathrm{aA}$ & $3.71 \mathrm{bA}$ \\
\hline 42 & $42.45 \mathrm{bcA}$ & $43.00 \mathrm{abA}$ & $8.12 \mathrm{eA}$ & $9.80 \mathrm{cA}$ & $3.58 \mathrm{aA}$ & $4.59 \mathrm{abA}$ \\
\hline General average & 43.51 & 42.25 & 12.96 & 12.92 & 4.97 & 5.60 \\
\hline $\mathrm{CV}(\%)$ & 4.67 & 6.40 & 5.15 & 9.38 & 37.44 & 19.28 \\
\hline
\end{tabular}

Note. ${ }^{1}$ Averages followed by the same lowercase letter in the column and upper case in the line do not differentiate by the Tukey test and $\mathrm{T}(\mathrm{p} \leq 0.05)$, respectively.

The number of bean grains pod $^{-1}$ was higher when the control of the alexandergrass was carried out up to 35 DAE, contrary to the observed in the coexistence group in which the management performed at 0,7 and 14 DAE presented lower number of grains $\operatorname{pod}^{-1}$ when compared to the later controls (Table 2). When comparing the periods with each other, it was observed that the control at 0 and 7 showed lower number of grains per pod when compared to the control group (Table 2). On the other hand, the control performed at the 42 DAE showed the lowest production of the number of grains pods $s^{-1}$ in relation to the coexistence evaluated at the same time.

The results referring to the mass of a thousand grains show that in the control period there were no significant differences between the evaluated treatments (Table 2). The coexistence of the beans with the alexandergrass at 7 DAE presented the lowest mass of a thousand grains when comparing with the other treatments and also in relation to the control period, since this time differed statistically with lower production. Similar data were observed by Barroso et al. (2010), when they verified that the mass of a thousand grains of the bean was reduced when in competition with Amaranthus and hairy beggarticks.

The results show no differences for the number of plant ${ }^{-1}$ pods for the control of alexandergrass in all the weeding periods (Table 2). In the group of treatments related to coexistence, there was a reduction in the number of plant $^{-1}$ pods when the crop coexisted with the alexandergrass in the initial phase. Possibly this is related to a new reflux of weeds in the area after the weeding, from 0 to 14 DAE. When comparing the group living with the control, the influence of the competition was more clearly denoted, especially when the alexandergrass lived at 0 and 7 DAE with a lower number of plant ${ }^{-1}$ pods, a fact that can be related to the lower emission of inflorescences and also to the abortion of these (Freitas et al., 2009).

In general, the weeding at 0 and 7 DAE showed lower number of grains per pods, number of pods, and weight of one thousand grains for the periods of cohabitation of the alexandergrass and beans (Table 2). The coexistence of the beans with the alexandergrass in these same two periods ( 0 and 7 DAE) showed lower production of number of grains per pods, number of pods per plant and mass of a thousand grains when compared with the control. In this way, it can be seen that the management of the alexandergrass in beans needs to be carried out at the beginning of the development of the crop, because if not controlled, it will exert a negative influence on the bean yield compendents (number of beans per pods, number of pods plant and mass of one thousand grains), which consequently will reflect in the decrease of grain yield. These data corroborate with those found by Stagnari et al. (2011) observed a reduction in some grain components of the bean, according to the increase of the population of weeds weeds of the culture. 
Table 2. Effect of cohabitation or control periods of Urochloa plantaginea (alexandergrass) on the number of grains pods ${ }^{-1}$, mass of one thousand grains $(\mathrm{g})$ and number of pods per black bean plant, IPR Uirapuru cultivar. UFFS, Erechim/RS, 2017/18

\begin{tabular}{|c|c|c|c|c|c|c|}
\hline \multirow{2}{*}{ Period in DAE } & \multicolumn{2}{|c|}{ Number of grains pods ${ }^{-1}$} & \multicolumn{2}{|c|}{ Thousand grains mass $(\mathrm{g})$} & \multicolumn{2}{|c|}{ Number od pods plants $^{-1}$} \\
\hline & Coexistence & Control & Coexistence & Control & Coexistence & Control \\
\hline 0 & $4.50 \mathrm{abB}^{1}$ & $5.60 \mathrm{abA}$ & $180.01 \mathrm{abA}$ & $200.50 \mathrm{aA}$ & $3.75 \mathrm{bB}$ & $14.00 \mathrm{aA}$ \\
\hline 7 & $3.76 \mathrm{bB}$ & $5.52 \mathrm{abA}$ & $169.72 \mathrm{bB}$ & $211.53 \mathrm{aA}$ & $3.40 \mathrm{bB}$ & $15.95 \mathrm{aA}$ \\
\hline 14 & $4.71 \mathrm{abA}$ & $5.97 \mathrm{aA}$ & $197.25 \mathrm{abA}$ & $208.89 \mathrm{aA}$ & $7.60 \mathrm{abA}$ & $13.20 \mathrm{aA}$ \\
\hline 21 & $5.24 \mathrm{aA}$ & $5.57 \mathrm{abA}$ & $197.36 \mathrm{abA}$ & $197.30 \mathrm{aA}$ & $12.30 \mathrm{aA}$ & $13.00 \mathrm{aA}$ \\
\hline 28 & $5.37 \mathrm{aA}$ & $5.42 \mathrm{abA}$ & $192.98 \mathrm{abA}$ & $215.94 \mathrm{aA}$ & $11.05 \mathrm{aA}$ & $13.40 \mathrm{aA}$ \\
\hline 35 & $5.25 \mathrm{aA}$ & $5.32 \mathrm{abA}$ & $209.07 \mathrm{aA}$ & $205.60 \mathrm{aA}$ & $9.85 \mathrm{aA}$ & $11.65 \mathrm{aA}$ \\
\hline 42 & $5.63 \mathrm{aA}$ & $4.60 \mathrm{bB}$ & $201.41 \mathrm{abA}$ & $187.09 \mathrm{aA}$ & $10.70 \mathrm{aA}$ & $10.30 \mathrm{aA}$ \\
\hline General average & 4.92 & 5.43 & 192.54 & 203.84 & 8.37 & 13.07 \\
\hline C.V $(\%)$ & 11.41 & 9.93 & 7.17 & 6.52 & 27.10 & 23.47 \\
\hline
\end{tabular}

Note. ${ }^{1}$ Averages followed by the same lowercase letter in the column and upper case in the line do not differentiate by the Tukey test and $\mathrm{T}(\mathrm{p} \leq 0.05)$, respectively.

When analyzing the stomatal conductance of the bean living with the alexandergrass, treatments 0 and 14 DAE showed significant differences when compared to each other, however, they were equal to the other treatments (Table 3). For the control, in this same variable did not occur differentiation between the different periods tested. At 35 DAE, the difference between the coexistence and control periods was observed, being less conductance in the coexistence with the alexandergrass than in the control. The reduction in stomatal conductance is closely linked to the characteristics of the cultivar and the environmental conditions to which they are subjected (Costa et al., 2007). The reduction in stomatal conductance occurred with black bean plants in competition with hairy beggarticks (Manebe et al., 2014), as well as in cowpea plants under stress conditions (Nascimento et al., 2011).

Table 3. Effect of cohabitation or control periods of Urochloa plantaginea (alexandergrass) on stomatal conductance (Gs-mol m $\left.\mathrm{m}^{-1} \mathrm{~s}^{-1}\right)$, internal $\mathrm{CO}_{2}$ concentration $\left(\mathrm{Ci}-\mu \mathrm{mol} \mathrm{mol}{ }^{-1}\right)$ and photosynthetic activity $(\mathrm{A}-\mu \mathrm{mol}$ $\mathrm{mol}^{-1}$ ) of black beans, IPR Uirapuru cultivar. UFFS, Erechim/RS, 2017/18

\begin{tabular}{|c|c|c|c|c|c|c|}
\hline \multirow{2}{*}{ Period in DAE } & \multicolumn{2}{|c|}{ Stomatal Conductance (Gs) } & \multicolumn{2}{|c|}{ Internal $\mathrm{CO}_{2}$ concentration $(\mathrm{Ci})$} & \multicolumn{2}{|c|}{ Photosynthetic activity (A) } \\
\hline & Coexistence & Control & Coexistence & Control & Coexistence & Control \\
\hline 0 & $1.31 \mathrm{aA}^{1}$ & $0.65 \mathrm{aA}$ & $255.00 \mathrm{aA}$ & $295.66 \mathrm{aA}$ & $19.90 \mathrm{aA}^{1}$ & $15.80 \mathrm{aA}$ \\
\hline 7 & $1.07 \mathrm{abA}$ & $0.62 \mathrm{aA}$ & $281.62 \mathrm{aA}$ & $295.66 \mathrm{aA}$ & $20.00 \mathrm{aA}$ & $15.24 \mathrm{aA}$ \\
\hline 14 & $0.71 \mathrm{bA}$ & $0.63 \mathrm{aA}$ & $285.87 \mathrm{aA}$ & $257.83 \mathrm{aA}$ & $19.27 \mathrm{aA}$ & $20.27 \mathrm{aA}$ \\
\hline 21 & $0.82 \mathrm{abA}$ & $1.02 \mathrm{aA}$ & $291.75 \mathrm{aA}$ & $277.83 \mathrm{aA}$ & $19.63 \mathrm{aA}$ & $17.76 \mathrm{aA}$ \\
\hline 28 & $0.94 \mathrm{abA}$ & $1.02 \mathrm{aA}$ & $278.50 \mathrm{aA}$ & $296.66 \mathrm{aA}$ & $20.62 \mathrm{aA}$ & $20.33 \mathrm{aA}$ \\
\hline 35 & $0.81 \mathrm{abB}$ & $0.93 \mathrm{aA}$ & $277.31 \mathrm{aA}$ & $305.83 \mathrm{aA}$ & $21.57 \mathrm{aA}$ & $20.46 \mathrm{aA}$ \\
\hline 42 & $1.06 \mathrm{abA}$ & $0.92 \mathrm{aA}$ & $277.33 \mathrm{aA}$ & $296.33 \mathrm{aA}$ & $23.37 \mathrm{aA}$ & $17.94 \mathrm{aA}$ \\
\hline General average & 0.96 & 0.83 & 278.19 & 298.40 & 20.62 & 18.26 \\
\hline CV (\%) & 23.79 & 22.21 & 14.38 & 9.80 & 27.45 & 25.95 \\
\hline
\end{tabular}

Note. ${ }^{1}$ Averages followed by the same lowercase letter in the column and upper case in the line do not differentiate by the Tukey test and $\mathrm{T}(\mathrm{p} \leq 0.05)$, respectively.

The results show for the variables related to the physiology of bean plants, internal $\mathrm{CO}_{2}$ concentration, photosynthetic activity (Table 3) and the transpiration rate (Table 4) that there was no statistically significant difference between the treatments, both for coexistence and for the control or even in the comparison of each period in the comparison between coexistence and control. Similar results were found by Ferraz et al. (2001) evaluated the gas exchange of different common bean in the semi-arid and by Matos et al. (2013) when studying the effect of competition of M. aterrima, U. plantaginea and $U$. decumbens on the coffee crop. Different from that found by Manebe et al. (2014) in which hairy beggarticks interference negatively influenced the physiological characteristics: $\mathrm{CO}_{2}$ consumption, transpiration rate and mainly photosynthetic activity. 
In Table 4, for the carboxylation efficiency, it was observed that the weeding at 14 and 35 DAE in the coexistence group differed from each other, but were the same as the other treatments. For the control group, there were no significant differences between the evaluated periods. At 35 and 42 DAE, it was observed that alexandergrass control, when compared to coexistence, negatively affected the carboxylation efficiency of the bean. Manabe et al. (2014) found results similar to the present study when the common bean competed with weeds, it can still be said that the reduction in the carboxylation efficiency is directly linked to the reduction of the internal concentration of $\mathrm{CO}_{2}$ and reduction of its assimilation rates (Ferraz et al., 2012).

In water efficiency, which consists of the amount of $\mathrm{CO}_{2}$ set for biomass production, as a function of the amount of water transpired (Ferreira et al., 2011), it is possible to denote that the coexistence of the beans with the alexandergrass of the 0 to $42 \mathrm{DAE}$ did not significantly alter it (Table 4). In the control group, it was observed that the weeding of the alexandergrass only at $0 \mathrm{DAE}$ was not enough for the beans to express better efficiency in water use when comparing with the other treatments. When comparing the coexistence and the control between them, it was noted that the efficiency of water use was lower for the control performed at 0 and 42 DAE.

Table 4. Effect of cohabitation or control periods of Urochloa plantaginea (alexandergrass) on the efficiency of carboxylation (EC-mol $\mathrm{CO}_{2} \mathrm{~m}^{-2} \mathrm{~s}^{-1}$ ), efficient use of water (EUA-mol $\mathrm{CO}_{2} \mathrm{~mol} \mathrm{H}_{2} \mathrm{O}^{-1}$ ) and transpiration rate $\left(\mathrm{E}-\mathrm{mol} \mathrm{H}_{2} \mathrm{O} \mathrm{m}^{-1} \mathrm{~s}^{-1}\right.$ ) of the black beans, IPR Uirapuru cultivar. UFFS, Erechim/RS, 2017/18

\begin{tabular}{|c|c|c|c|c|c|c|}
\hline \multirow{2}{*}{ Period in DAE } & \multicolumn{2}{|c|}{ Efficiency of carboxylation (EC) } & \multicolumn{2}{|c|}{ Efficient use of water (EUA) } & \multicolumn{2}{|c|}{ Transpiration rate $(\mathrm{E})$} \\
\hline & Coexistence & Control & Coexistence & Control & Coexistence & Control \\
\hline 0 & $0.07 \mathrm{abA}^{1}$ & $0.06 \mathrm{aA}$ & $2.04 \mathrm{aA}$ & $1.16 \mathrm{bB}$ & $9.83 \mathrm{aA}$ & $9.94 \mathrm{aA}$ \\
\hline 7 & $0.07 \mathrm{abA}$ & $0.05 \mathrm{aA}$ & $2.16 \mathrm{aA}$ & $1.90 \mathrm{abA}$ & $9.73 \mathrm{aA}$ & $8.62 \mathrm{aA}$ \\
\hline 14 & $0.06 \mathrm{bA}$ & $0.07 \mathrm{aA}$ & $1.95 \mathrm{aA}$ & $2.02 \mathrm{aA}$ & $9.90 \mathrm{aA}$ & $10.02 \mathrm{aA}$ \\
\hline 21 & $0.07 \mathrm{abA}$ & $0.06 \mathrm{aA}$ & $2.19 \mathrm{aA}$ & $1.75 \mathrm{abA}$ & $9.45 \mathrm{aA}$ & $10.53 \mathrm{aA}$ \\
\hline 28 & $0.07 \mathrm{abA}$ & $0.06 \mathrm{aA}$ & $2.11 \mathrm{aA}$ & $2.05 \mathrm{aA}$ & $9.55 \mathrm{aA}$ & $9.89 \mathrm{aA}$ \\
\hline 35 & $0.12 \mathrm{aA}$ & $0.06 \mathrm{aB}$ & $3.27 \mathrm{aA}$ & $2.23 \mathrm{aA}$ & $8.95 \mathrm{aA}$ & $9.67 \mathrm{aA}$ \\
\hline 42 & $0.10 \mathrm{abA}$ & $0.06 \mathrm{aB}$ & $2.69 \mathrm{aA}$ & $1.93 \mathrm{abB}$ & $10.12 \mathrm{aA}$ & $9.30 \mathrm{aA}$ \\
\hline General average & 0.08 & 0.06 & 2.34 & 1.86 & 9.65 & 9.71 \\
\hline CV (\%) & 26.64 & 29.14 & 25.20 & 18.69 & 11.89 & 18.34 \\
\hline
\end{tabular}

Note. ${ }^{1}$ Averages followed by the same lowercase letter in the column and upper case in the line do not differentiate by the Tukey test and $\mathrm{T}(\mathrm{p} \leq 0.05)$, respectively.

Figure 1 shows the yield curves of the black bean as a function of the coexistence or control of the weeds. It is observed that the coexistence with the alexandergrass began to affect the bean crop 24 days after the emergency (DAE), thus observing the need of the control of the alexandergrass until the 50 DAE. The interval between 24 and 50 DAE corresponds to the critical period of interference prevention (CPIP) in the Upper Uruguay Region of Rio Grande do Sul. While the period prior to 24 DAE is characterized as the period before interference (PBI), in which, the weed can coexist with the crop without reducing grain yield. It is noticed that at the end of the PBI would be the recommended period for the first control of the weeds, in this case the papuan. The total period of interference prevention (TPIP) was 50 days, and the weeds that emerged after this period did not affect the final yield of the crop or would have caused the maximum possible damage.

In crops where chemical weed control is adopted, herbicides applied in pre-emergence should have a residual effect that includes 50 DAE or so-called TPIP, since the plants that emerge after this phase did not significantly reduce crop productivity. In crops that are applied post-emergence herbicides or performed mechanical control of the alexandergrass, these operations must start at 24 DAE and end at 50 DAE at CPIP. 


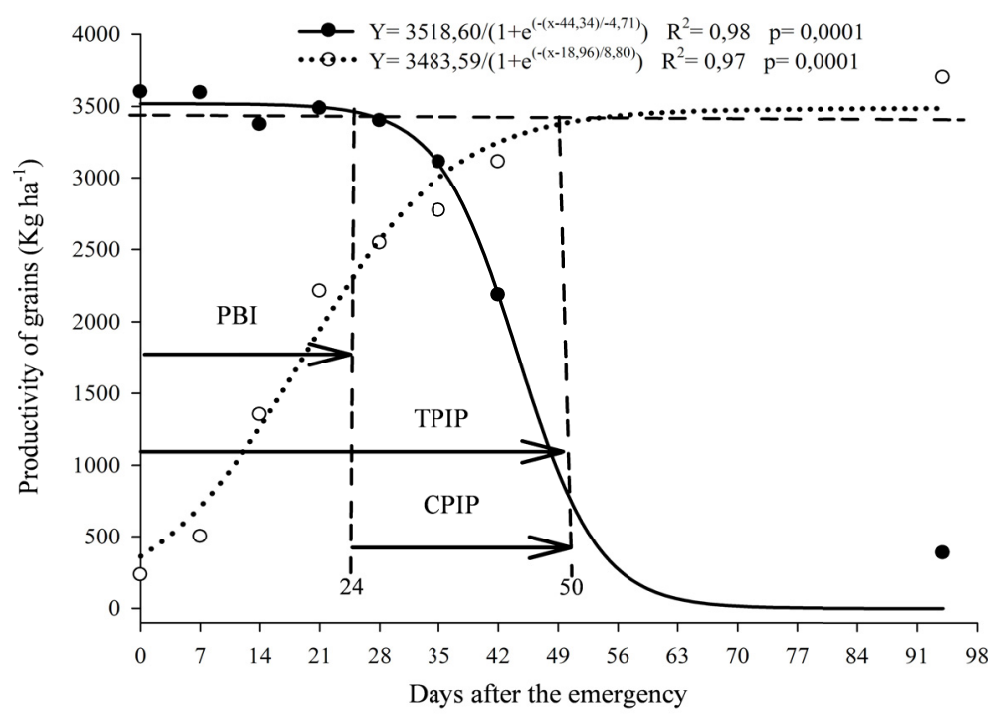

Figure 1. Bean grain yield $\left(\mathrm{kg} \mathrm{ha}^{-1}\right)$ IPR Uirapuru cultivar, due to infestation by different periods of coexistence (•) and control (O) of Urochloa plantaginea (alexandergrass). PBI: period before interference; TPIP: total period of interference prevention and CPIP: critical period of interference prevention.

UFFS, Erechim/RS, 2017/18

Parreira et al. (2014) observed in the study conducted for the determination of the period before interference of Raphanus raphanistrum, Digitaria sp., Cyperus rotundus, Xantium strumarium and Portulacacea oleraceae on bean cultivars with different growth habits, which averaged 20 DAE, independent of the growth habit of the cultivars of the crop.

According to studies by Borchartt et al. (2011) for determination of the interference periods of $D$. horizontalis and Zea mays L. in common bean, showed that the period before the interference extends to $4 \mathrm{DAE}$, the critical period of interference prevention corresponds to the period from 4 to $18 \mathrm{DAE}$, so the total period of interference prevention is up to 18 DAE.

The definition of CPIP in black bean crop and other crops is an extremely important tool for the adoption of integrated weed management in order to mitigate losses and unnecessary use of herbicides. However, the precise determination of this period is extremely complex, because factors such as sowing season and plant population of the crop; dose and times of application of nitrogen fertilization; species and weed populations present in the area; and soil and climatic characteristics can considerably influence the results, causing differences in different locations and years.

\section{Conclusions}

Due to competition for resources by the alexandergrass, it is noted that the morphological variables: plant height, number of trifoliate leaves, number of pods per plant, number of grains per pod, dry mass and mass of one thousand grains are negatively influenced, resulting in low crop productivity.

The variables related to the physiology of black bean plants cultivar IPR Uirapuru are little influenced by the effect of alexandergrass competition.

The period that black beans, cultivar IPR Uirapuru, and alexandergrass can coexist without negative interference in grain yield (PBI) is up to $24 \mathrm{DAE}$. The period in which the crop should remain free of interference so that grain yield is not affected (TPIP) is up to 50 DAE and the critical period of control (CPIP) of the alexandergrass comprises the range from 24 to 50 DAE of the bean cultivate IPR Uirapuru.

The determination of CPIP is important for proper weed management in order to avoid losses and unnecessary use of herbicides.

\section{References}

Agostinetto, D., Rigoli, R. P., Schaedler, C. E., Tironi, S. P., \& Santos, L. S. (2008). Período crítico de competição de plantas daninhas com a cultura do trigo. Planta Daninha, 26, 271-278. https://doi.org/ $10.1590 / \mathrm{S} 0100-83582008000200003$ 
Balbinot, C. R., Dariva, P. A., Sordi, A., Lajús, C. R., Cericato, A., Luz, G. L., \& Klein, C. (2016). Período crítico de interferência das plantas daninhas na cultura do milho. Unoesc \& Ciência, 7, 211-218.

Barroso, A. A. M., Yamauti, M. S., \& Alves, P. L. da C. A. (2010). Interferência entre espécies de planta daninha e duas cultivares de feijoeiro em duas épocas de semeadura. Bragantia, 69, 609-616. https://doi.org/ 10.1590/S0006-87052010000300012

Borchartt, L., Jakelaitis, A., Valadão, F. C. de A., Venturoso, L. A. C., \& Santos, C. L. dos. (2011). Períodos de interferência de plantas daninhas na cultura do feijoeiro-comum (Phaseolus vulgaris L.). Revista Ciência Agronômica, 42, 725-735. https://doi.org/10.1590/S1806-66902011000300019

CONAB (Companhia Nacional De Abastecimento). (2017). Acompanhamento da safra brasileira de grãos. Retrieved from http://www.conab.gov.br/OlalaCMS/uploads/arquivos/18_01_11_09_53_59_graos_4o_leva ntamento.pdf. Acessado em 30 de janeiro de 2018.

CONAB (Companhia Nacional De Abastecimento). (2018). Série Histórica de: Área, produtividade e produção. Feijão, Brazil. Retrieved June 20, 2018, from http://www.conab.gov.br

Costa, G. F., \& Marenco, R. A. (2007). Fotossíntese, condutância estomática e potencial hídrico foliar em árvores jovens de andiroba (Carapa guianensis). ACTA Amozônia, 37, 229-234. https://doi.org/10.1590/ S0044-59672007000200008

Cousens, R. (1985). A simple model relating yield loss to weed density. Ann Appl Biol, 107, $239-252$. https://doi.org/10.1111/j.1744-7348.1985.tb01567.x

EMBRAPA (Empresa Brasileira De Pesquisa Agropecuária). (2013). Sistema brasileiro de classificação de solos. EMBRAPA, Brasília.

Ferraz, L. R. S., Melo, A. S. de, Suassuna, J. F., Brito, M. E. B. de, Fernandes, P. D., \& Júnior, E. da S. N. (2012). Trocas gasosas e eficiência fotossintética em ecótipos de feijoeiro cultivados no semiárido. Pesquisa Agropecuária Tropical., 42, 181-188. https://doi.org/10.1590/S1983-40632012000200010

Ferreira, E. A., Ignacio, A. I., Galon, L., Concenço, G., Silva, A. F. \& Reis, L. A. C. (2011). Características fisiológicas da soja em relação a espécies de plantas daninhas. Revista Trópica-Ciências Agrárias e Biológicas, 5, 39-47.

Fleck, N. G., Rizzardi, M. A., Vidal, R. A., Merotto Jr., A., Agostinetto, D., \& Balbinot Jr., A. A. (2002). Período crítico para controle de Brachiaria plantaginea em função de épocas de semeadura da soja após dessecação da cobertura vegetal. Planta Daninha, 20, 53-62. https://doi.org/10.1590/S0100-83582002000100008

Freitas, F. C. L., Medeiros, V. F. L. P., Grangeiro, L. C., Silva, M. G. O., Nascimento, P. G. M. L., \& Nunes, G. H. (2009). Interferência de plantas daninhas na cultura do feijão-caupi. Planta Daninha, 27, $241-247$. https://doi.org/10.1590/S0100-83582009000200005

Galon, L., Pinto, J. J. O., Rocha, A. A., Concenço, G., Silva, A. F., \& Aspiazú, I. (2008). Períodos de interferência de Brachiaria plantaginea na cultura do milho na região sul do rio grande do sul. Planta Daninha, 26, 779-788. https://doi.org/10.1590/S0100-83582008000400009

Lacerda, C. F., Carvalho, C. M., Vieira, M. R., Américo, J. G., Neves, A. L. R., \& Rodrigues, C. F. (2010). Análise de crescimento de milho e feijão sob diferentes condições de sombreamento. Revista Brasileira de Ciências Agrárias, 5, 18-24. https://doi.org/10.5039/agraria.v5i1a485

Lamego, F. P., Fleck, N. G., Bianchi, M. A., \& Schaedler, C. E. (2004). Tolerância à interferência de plantas competidoras e habilidade de supressão por genótipos de soja-II. Resposta de variáveis de produtividade. Planta Daninha, 22, 491-498. https://doi.org/10.1590/S0100-83582004000400002

Manabe, P. M. S., Matos, C. da C. de, Ferreira, E. A., Silva, A. A. da, Sediyama, T., \& Manabe, A. (2014). Características fisiológicas de feijoeiro em competição com plantas daninhas. Biocience Journal, 30, 1721-1728.

Manabe, P. M. S., Matos, C. da C. de, Ferreira, E. A., Silva, A. A. da, Sediyama, T., \& Manabe A. (2015). Efeito da competição de plantas daninhas na cultura do feijoeiro. Biocience Journal, 33, 333-343. https://doi.org/ $10.14393 / \mathrm{bj}-\mathrm{v} 31 \mathrm{n} 2 \mathrm{a} 2015-22271$

Matos, C.C., Fialho, C. M. T., Ferreira, E. A., Silva, D. V., Silva, A. A., \& Santos, J. B. (2013). Características fisiológicas do cafeeiro em competição com plantas daninhas. Biocience Journal, 29, 1111-1119. 
Meschede, D. K., Oliveira Jr., R. S., Constantin, J., \& Scapim, C. A. (2004). Período anterior à interferência de plantas daninhas em soja: estudo de caso com baixo estande e testemunhas duplas. Planta Daninha, 22, 239-246. https://doi.org/10.1590/S0100-83582004000200010

Moreira, H. J. C. (2011). Manual de identificação de plantas infestantes: Hortifrúti. FMC Agricultural Products, São Paulo.

Parreira, M. C., Alves, P. L. C. A., Lemos, L. B., \& Portugal, J. (2014). Comparação entre métodos para determinar o período anterior à interferência de plantas daninhas em feijoeiros com distintos tipos de hábitos de crescimento. Planta Daninha, 32, 727-738. https://doi.org/10.1590/S0100-83582014000400007

Procópio, S. O., Santos, J. B., Silva, A. A., Martinez, C. A., \& Werlang, R. C. (2004). Características fisiológicas das culturas de soja e feijão e três espécies de plantas daninhas. Planta Daninha, 22, 211-216. https://doi.org/10.1590/S0100-83582004000200006

ROLAS (Rede Oficial de Laboratórios de Análise de Solo e de Tecido Vegetal). (2004). Manual de adubação e calagem para os estados do Rio Grande do Sul e Santa Catarina. Sociedade Brasileira de Ciência do Solo, Porto Alegre.

Scholten, R., Parreira, M. C., \& Alves, P. L. C. A. (2011). Período anterior à interferência das plantas daninhas para a cultivar de feijoeiro 'Rubi' em função do espaçamento e da densidade de semeadura. Acta Scientiarum. Agronomy, 33, 313-320. https://doi.org/10.4025/actasciagron.v33i2.5646

Silva, A. F., Ferreira, E. A., Concenço, G., Ferreira, F. A., Aspiazu, I., \& Galon, L. (2008). Densidades de plantas daninhas e épocas de controle sobre os componentes de produção da soja. Planta Daninha, 26, 65-71. https://doi.org/10.1590/S0100-83582008000100007

Silva, A. F., Concenço, G., Aspiazú, I., Ferreira, E. A., Galon, L., \& Coelho, A. T. C.P. (2009a). Interferência de plantas daninhas em diferentes densidades no crescimento da soja. Planta Daninha, 27, 75-84. https://doi.org/10.1590/S0100-83582009000100011

Silva, A. F., Concenço, G., Aspiazú, I., Ferreira, E. A., Galon, L., \& Freitas, M. A. M. (2009b). Período anterior à interferência na cultura da soja-RR em condições de baixa, média e alta infestação. Planta Daninha, 27, 57-66. https://doi.org/10.1590/S0100-83582009000100009

Stagnari, F., \& Pisante, M. (2011). The critical period for weed competition in French bean (Phaseolus vulgaris L.) in Mediterranean areas. Crop Protection, 30, 179-184. https://doi.org/10.1016/j.cropro.2010.11.003

Taiz, L., Zeiger E., Moller, I. M., \& Murphy A. (2017). Fisiologia e desenvolvimento vegetal. Artmed, Porto Alegre.

Vidal, R. A., Kalsing A., \& Gherekhloo J. (2010). Interferência e nível de dano econômico de Brachiaria plantaginea e Ipomoea nil na cultura do feijão comum. Ciência Rural, 40, 1675-1681. https://doi.org/ $10.1590 / \mathrm{S} 0103-84782010000800001$

Xiao-ya, M. A., Han-wen, W. U., Wei-li J., Ya-jie, M. A., \& Yan, M. A. (2015). Goosegrass (Eleusine indica) density effects on cotton (Gossypium hirsutum). Journal of Integrative Agriculture, 14, 1778-1785. https://doi.org/10.1016/S2095-3119(15)61058-9

\section{Copyrights}

Copyright for this article is retained by the author(s), with first publication rights granted to the journal.

This is an open-access article distributed under the terms and conditions of the Creative Commons Attribution license (http://creativecommons.org/licenses/by/4.0/). 